\title{
How American eels Anguilla rostrata construct and respire in burrows
}

\author{
J. P. N. Tomie ${ }^{1}$, D. K. Cairns ${ }^{2, *}$, S. C. Courtenay ${ }^{1}$ \\ ${ }^{1}$ Fisheries and Oceans Canada at the Canadian Rivers Institute, Biology Department, University of New Brunswick, \\ Fredericton, New Brunswick E3B 5A3, Canada \\ ${ }^{2}$ Fisheries and Oceans Canada, Box 1236, Charlottetown, Prince Edward Island C1A 7M8, Canada
}

\begin{abstract}
We investigated the burrowing behaviour of growth-phase (yellow) American eel Anguilla rostrata, a nocturnal fish that occupies the substrate during daylight hours and during winter. Eels formed burrows by forcing the head, then the body, into the substrate with rapid body undulations. Eels excavated from mud showed highly variable postures. In 10 of 15 experiments, the eel's mouth was at or slightly above the surface. In the remaining experiments, the eel's mouth was a mean of $3.5 \mathrm{~cm}$ below the surface, and an inhalation shaft ran from the surface to the mouth. Eels probably advance through mud by alternately pushing and anchoring the anterior and posterior parts of the body. Eel burrows observed in the lab and the field had up to 5 openings. Craters or mounds formed around some winter burrow openings due to head or tail movements or sediment erosion. Flat openings and openings in which the eel plugged the burrow entrance were found in both summer and winter. Dye trace experiments indicated that eels in mud and pebble burrows draw water from the water column into the mouth and exhale it through the gill openings. Because eels in burrows use water from the water column for respiration, the spread of anthropogenically induced anoxia and hypoxia in coastal waters poses an increasing conservation threat.
\end{abstract}

KEY WORDS: Burrowing behaviour $\cdot$ Burrow morphology $\cdot$ Branchial respiration

\section{INTRODUCTION}

American eels Anguilla rostrata begin their lives in the Sargasso Sea, from which leptocephali larvae are carried toward the West Atlantic shore by ocean currents. These larvae metamorphose into unpigmented glass eels, then elvers, and then yellow eels, which grow until metamorphosis to silver eels, which return to the Sargasso Sea to spawn and die (Tesch 2003). American eels, along with other temperate Anguilla species, are termed facultatively catadromous because they may occupy either fresh or salt water during their yellow (growth) phase (Lamson et al. 2006, Jessop et al. 2008).

Recent declines in Anguilla spp. abundance indices in Europe and the West Pacific have triggered fears of a generalised collapse in anguillid eel populations (Dekker et al. 2003). The American eel is panmictic, meaning that the species forms a single stock (Cote et al. 2013). Nevertheless, population trends vary markedly across the species' range. American eel recruitment to the formerly large population in the upper St. Lawrence River and Lake Ontario has declined by more than $98 \%$, but abundance indices in some parts of Atlantic Canada are stable or increasing (Cairns et al. 2008, Marcogliese \& Casselman 2009). The American eel has been assessed as Threatened in Canada (COSEWIC 2012), but in the United States, the US Department of the Interior (2007) concluded that that listing was unwarranted. Reviews of conservation status have emphasised negative effects of dams, contaminants, and fishing, 
but no clear link has been established between any threat and the total size of the panmictic population (Casselman 2003, COSEWIC 2012).

Some fish species spend much or most of their time in the substrate, either in self-dug burrows (Atkinson \& Taylor 1991) or in natural cavities (Ménard et al. 2008). Substrate occupancy may reduce the risk of predation, protect against strong currents, or serve as a base for feeding (Bozzano 2003, Ménard et al. 2008). Yellow-stage anguillid eels generally forage nocturnally, but spend the day in the substrate, either in burrows excavated in soft sediments, or in spaces among rocks or bottom debris (Glova 2002, Tesch 2003). In temperate regions, anguillid eels occupy the substrate throughout winter (Smith \& Saunders 1955, Thomas 1968). Aoyama et al. (2005) made resin casts of burrows excavated by Japanese eels Anguilla japonica (Temminck \& Schlegel 1846) in a tidal channel, and found that burrows had up to 3 openings and ranged in depth from 18 to $30 \mathrm{~cm}$. Wintering burrows of American eels may show a visible depression (pock mark) at the surface (Smith \& Saunders 1955), but visible marks have not been reported for summer burrows. In eastern Canada, Vladykov (1955) reported that several eels may share the same wintering hole in fresh water.

Seafloors of many bays, estuaries, and inland waters of eastern North America have been profoundly altered by dredging, construction, and agricultural, industrial, and municipal run-off (Colodey \& Wells 1992, Santiago \& Pelletier 2001, Lotze et al. 2006). Eel conservation is potentially affected by both physical and chemical changes to these habitats. Like other burrowing fishes, eels require access to oxygen, which is present in limited supply in sediments (Behrens et al. 2007, Weissberger et al. 2009). Since eels readily absorb contaminants from sediments (Benedetti et al. 2008), they may also be affected by seafloor pollutants. Anthropogenic eutrophication is a major threat to estuarine ecosystems, and may lead to anoxic or hypoxic conditions in bottom waters (Kennish 2002). Any comprehensive examination of threats to American eel conservation should therefore consider impacts that may occur while eels occupy substrate refuges. An understanding of the behaviour and ecology of eel substrate occupancy is a necessary precursor to such an evaluation.

The objective of the present study is to determine how American eels construct, utilise, and respire in burrows and other substrate refuges. Data were obtained from laboratory experiments and from field studies carried out in the Maritime Provinces of Canada.

\section{MATERIALS AND METHODS}

\section{Burrowing behaviour}

Burrowing behaviour of Anguilla rostrata was recorded in the lab during substrate selection experiments (Tomie 2011), excavation experiments, dye respiration experiments, and in the field from a glassbottomed boat. Yellow American eels used in lab experiments were collected by rotary screw trap from the Nashwaak River, New Brunswick (NB) $\left(46.118^{\circ} \mathrm{N}, 66.608^{\circ} \mathrm{W}\right)$ and from commercial fyke net fisheries in French Lake, NB $\left(45.923^{\circ} \mathrm{N}, 66.293^{\circ} \mathrm{W}\right)$. Substrates used during experiments included mud (lower quartile, median, and upper quartile diameters of 221,112 , and $59 \mu \mathrm{m}$ respectively), mediumcoarse sand (lower quartile, median, and upper quartile diameters of 1449,781 , and $430 \mu \mathrm{m}$ respectively), pebbles (rounded pebble gravel; particle size: 0.5 to $1 \mathrm{~cm}$ ), gravel (angular pebble gravel; particle size: 2 to $5 \mathrm{~cm}$ ), and rounded cobble (4 to $20 \mathrm{~cm}$ long and 3 to $15 \mathrm{~cm}$ wide) (Wentworth 1922, Higgins \& Thiel 1988). Gravel and cobble substrates had previously been used in tanks that housed Atlantic salmon Salmo salar (Linnaeus 1758). Fresh mud was collected from the Nashwaaksis Stream, NB, and mixed with a shovel prior to use. The pebbles used in the present study were aquarium pebbles purchased from a pet supply store. Burrowing in mud, sand, pebbles, gravel, and cobble that was overlain by water was observed 52, 3, 6, 2, and 34 times respectively. Most observations were made in tanks $(200 \mathrm{~cm}$ length $\times 92 \mathrm{~cm}$ width $\times 92 \mathrm{~cm}$ height) used for substrate preference experiments (Tomie 2011), and during the excavation experiments and dye experiments conducted in the present study. Observations were made during the day, and at night with the aid of lights filtered by red, a colour to which eel retinas show little sensitivity (Damjanovic et al. 2005). Burrowing was observed at temperatures of 1.4 to $18.0^{\circ} \mathrm{C}$.

\section{Burrow morphology}

Three-dimensional burrow structure was mapped by excavating buried eels. Experiments were performed between October 2009 and April 2010 at the Mactaquac Biodiversity Facility, NB. An aquarium (61 cm length $\times 31 \mathrm{~cm}$ width $\times 41 \mathrm{~cm}$ height) was fitted with a perforated stand pipe $(27 \mathrm{~cm}$ long $\times 6 \mathrm{~cm}$ diameter; used for siphoning) in the corner, and then filled with 10 to $15 \mathrm{~cm}$ of mud and topped with 22 to $25 \mathrm{~cm}$ of fresh water. Water, pumped from the nearby 
Saint John River, was aerated with an air stone. Mud used in these experiments was obtained from the Nashwaaksis Stream, NB. Grain size analysis of the mud on the Wentworth scale (Wentworth 1922, Higgins \& Thiel 1988) classified the finest quartile of particle size as silt, the average particle size as very fine sand, and the largest quartile of particle size as fine sand.

Eels were measured (total length) and released singly into the aquarium. After $24 \mathrm{~h}$, water was siphoned off and the mud was carefully removed with a trowel. As the eel's body was exposed, its position was recorded to the nearest millimetre along $x_{1}$ $y$, and $z$-axes. From 4 to 23 coordinates were recorded for each experiment, with more than 10 coordinates recorded for 13 of the 15 successful experiments. Results from the experiment were discarded if the eel moved during excavation. Coordinates were plotted using SigmaPlot software, with the image rotated in 3D to give the clearest visual presentation of the eel's configuration. The curve ratio of buried eels was calculated as: distance between the tip of the head and the tip of the tail, divided by eel length. Eels with the head located near the tail, or with large body curvatures, had a low curve ratio, whereas eels with a straight body had a curve ratio of one.

Supplemental observations of burrow morphology were made during experiments in which eels chose among mud, sand, gravel, and cobble substrates (Tomie 2011). Characteristics of burrows made by free-living eels were investigated in the brackish estuary of the Morell River, Prince Edward Island $\left(46.418^{\circ} \mathrm{N}, 62.696^{\circ} \mathrm{W}\right)$ during day and night on 4 to 6 May and during the day of 9 December 2009, using a glass-bottom boat as an observation platform. White LED lights were used to illuminate nighttime observations. Water temperatures during the 2 observation periods were 12 and $3^{\circ} \mathrm{C}$, respectively. Salinity, measured by a YSI 85 salinometer, was 3.5 to 8 near the substrate surface and 0.5 to 0.6 near the water surface. The presence of pock marks on the substrate (Smith \& Saunders 1955) and eels observed at the burrow entrances confirmed that these were eel burrows. Pock marks are typical of wintering burrows but are not known for summering burrows; hence these burrows were considered wintering burrows. Burrow entrances were photographed with a scale bar lowered to the bottom for distance calibration. Burrow entrances were commonly found as clusters. Only clusters that were distant from other clusters were photographed to decrease the risk of mistaking several independent burrows as one.

\section{Mode of ventilation in burrows}

Following the approach of Behrens et al. (2007), ventilatory water flow of buried eels was tracked in dye experiments. A narrow compartment $(61 \times 9 \times$ $41 \mathrm{~cm}$ ) was constructed on one side of a glass aquarium. Pebbles ( 0.5 to $1 \mathrm{~cm}$ diameter) or mud were added and topped with fresh water. The compartment was sufficiently narrow so that the buried eel could be observed regardless of its position. Eels were released singly into the compartment. After burrowing took place and the eel settled (usually within a few minutes), 1 to $2 \mathrm{ml}$ of methylene blue dye was released by syringe into the water just above the eel's mouth. Standing water in the aquarium was then siphoned off to prevent dye from diffusing into the substrate from above. Five dye experiments were conducted: 2 with mud as substrate and 3 with pebbles as substrate.

\section{RESULTS}

\section{Burrowing behaviour}

Eels formed burrows in mud with a stereotypic behavioural sequence that was similar in day and night and in aquaria and the wild. The sequence typically started with the eel lying prone on the mud. In some cases, it performed brief horizontal head sweeps along the substrate prior to burrowing. The body was then lifted to an angle of $\sim 45^{\circ}$, and rapid body undulations forced the head into the mud. As the eel advanced, undulations continued at a lower intensity and the body gyrated slightly from side to side. After most of the body had entered the substrate, undulations above the water-substrate interface ceased. Visible movement sometimes paused at this point, before the remainder of the body advanced into the mud, apparently with the aid of within-substrate body movements. Eels typically took between 5 and $30 \mathrm{~s}$ at temperatures between 1.4 and $18^{\circ} \mathrm{C}$ to completely enter mud substrates. Often the snout would appear at another point on the substrate surface after the body disappeared.

Eels burrowed into rounded pebbles and coarsemedium sand using the same technique as for mud, although penetration was generally slower. Eels showed varying techniques in entering larger, angular gravel (particle size: 2 to $5 \mathrm{~cm}$ ). In some cases, eels readily entered the gravel using the same technique as mud burrowing. In others, eels attempted to force their way through gaps between stones, using rapid 
body undulations for propulsion. If initial attempts to open a route into the gravel were unsuccessful, the eel would push at a different angle, or re-start at a new entry point. Efforts to burrow into gravel sometimes persisted for hours or days. Once the head penetrated the gravel, the eel continued to force its body through the stones with rapid body movements. With cobble substrates, eels simply swam into interstitial spaces without the aid of burrowing behaviours. Larger eels required larger particle sizes for this to be possible. Typically, eels were able to swim into substrates with inter-particle spaces larger than the animal's body diameter.

Burrowing into mud in the absence of water began with the eel resting in a curved position on the surface. This position appeared to provide an anchor allowing the eel to force its head, then its body, into the mud. After the head entered the mud, the mud near the penetration point vibrated, suggesting an active role of the head region in creating the burrow. As the anterior half of the eel's body entered the mud, progress was more or less continuous, but as the posterior half entered, the eel progressed in 1-2 cm spurts, each followed by a brief pause.

Two escape behaviours of burrowed eels were observed. In the first, witnessed in the Morell River estuary, an eel whose head was protruding from a burrow opening quickly retracted it and then left head-first from another opening within $2 \mathrm{~s}$. The second response was observed during excavation exper- iments. When portions of the body were exposed, some eels maintained themselves within the substrate by burrowing deeper into the mud.

\section{Burrow morphology}

A total of 23 burrows were excavated, from which 15 valid 3-dimensional configurations were obtained (Table 1, Fig. 1). In 10 configurations, the tail was positioned above the maximum depth of the burrow, and in 5 configurations, the tail occupied the deepest part of the burrow. Maximum depth of the burrow ranged from 1.5 to $13.5 \mathrm{~cm}$, with a mean $( \pm \mathrm{SD})$ maximum depth of $7.8 \pm 3.9 \mathrm{~cm}$. In 3 of the experiments, the lowest eel depth was within $2 \mathrm{~cm}$ of the aquarium floor, which suggests that the depth of available mud may have constrained burrow configurations. Eels in the experiments lay in the mud in irregular curves, with a mean $( \pm \mathrm{SD})$ curve ratio of $0.70 \pm 0.17$ (range: 0.22 to 0.99 ) (Table 1 ).

All burrows had a vertical or oblique passage rising to the substrate surface. In 10 of 15 cases, the eel's head filled this passage and the snout was at or slightly above the surface. In the remaining cases, the snout was a mean of $3.5 \pm 2.0 \mathrm{~cm}$ (range: 1.5 to $6.0 \mathrm{~cm}$; Table 1) below the mud surface, and an inhalation shaft ran from the surface to the mouth. Inhalation shafts observed in winter experiments were approximately 3 to $4 \mathrm{~cm}$ long and 2 to $3 \mathrm{~cm}$ wide (approximately the same width as the eel).

Table 1. Anguilla rostrata. Characteristics of burrows made by captive eels in mud as determined by excavation experiments. Head angle is the angle of the head from the horizontal. Negative numbers for tip of head depth indicate height above substrate. na: not applicable

\begin{tabular}{|c|c|c|c|c|c|c|c|c|}
\hline Expt & $\begin{array}{c}\text { Date } \\
\text { (d mo yr) }\end{array}$ & $\begin{array}{c}\text { Temp. } \\
\left({ }^{\circ} \mathrm{C}\right)\end{array}$ & $\begin{array}{l}\text { Eel length } \\
\quad(\mathrm{cm})\end{array}$ & $\begin{array}{l}\text { Curve } \\
\text { ratio }\end{array}$ & $\begin{array}{c}\text { Head } \\
\text { angle }\left(^{\circ}\right)\end{array}$ & $\begin{array}{l}\text { Tip of head } \\
\text { depth }(\mathrm{cm})\end{array}$ & $\begin{array}{l}\text { Tail depth } \\
\text { (cm) }\end{array}$ & $\begin{array}{l}\text { Max. depth } \\
\text { (cm) }\end{array}$ \\
\hline 1 & 2 Oct 09 & 11.9 & 35.7 & 0.81 & 25 & -1.0 & 0.0 & 1.5 \\
\hline 2 & 8 Oct 09 & 12.1 & 33.4 & 0.74 & 60 & -0.5 & 3.0 & 5.0 \\
\hline 3 & 17 Nov 09 & 7.3 & 34.1 & 0.71 & 75 & 6.0 & 5.5 & 10.5 \\
\hline 4 & 18 Nov 09 & 7.6 & 29.1 & 0.99 & 35 & -0.5 & 13.0 & 13.0 \\
\hline 5 & 22 Nov 09 & 4.7 & 33.9 & 0.74 & 45 & -0.5 & 13.0 & 13.0 \\
\hline 6 & 25 Nov 09 & 6.2 & 44.7 & 0.69 & 35 & 0.0 & 6.0 & 9.0 \\
\hline 7 & 29 Nov 09 & 4.2 & 34.2 & 0.70 & 55 & -0.5 & 7.0 & 10.0 \\
\hline 8 & 24 Feb 10 & 1.4 & 40.5 & 0.81 & 90 & 5.1 & 13.5 & 13.5 \\
\hline 9 & 24 Mar 10 & 1.9 & 39.5 & 0.22 & 45 & -0.3 & 3.5 & 6.0 \\
\hline 10 & 29 Mar 10 & 3.4 & 43.1 & 0.58 & 90 & 3.0 & 5.5 & 10.0 \\
\hline 11 & 31 Mar 10 & 2.4 & 36.1 & 0.71 & 30 & 1.5 & 4.5 & 5.0 \\
\hline 12 & 06 Apr 10 & 6.0 & 30.7 & 0.77 & 30 & 2.0 & 3.0 & 3.0 \\
\hline 13 & 10 Apr 10 & 7.4 & 35.8 & 0.84 & 0 & -1.5 & 0.0 & 3.5 \\
\hline 14 & 27 Apr 10 & 5.8 & 35.1 & 0.56 & 70 & 0.0 & 2.0 & 6.0 \\
\hline 15 & 28 Apr 10 & 8.9 & 37.1 & 0.60 & 45 & -1.0 & 8.5 & 8.5 \\
\hline Mean & & 6.1 & 36.2 & 0.70 & 48.7 & 0.8 & 5.9 & 7.8 \\
\hline $\mathrm{SD}$ & & 3.3 & 4.3 & 0.17 & 25.0 & 2.3 & 4.4 & 3.9 \\
\hline $\mathrm{CV}$ & & 0.54 & 0.12 & 0.24 & 0.51 & & 0.76 & 0.49 \\
\hline
\end{tabular}



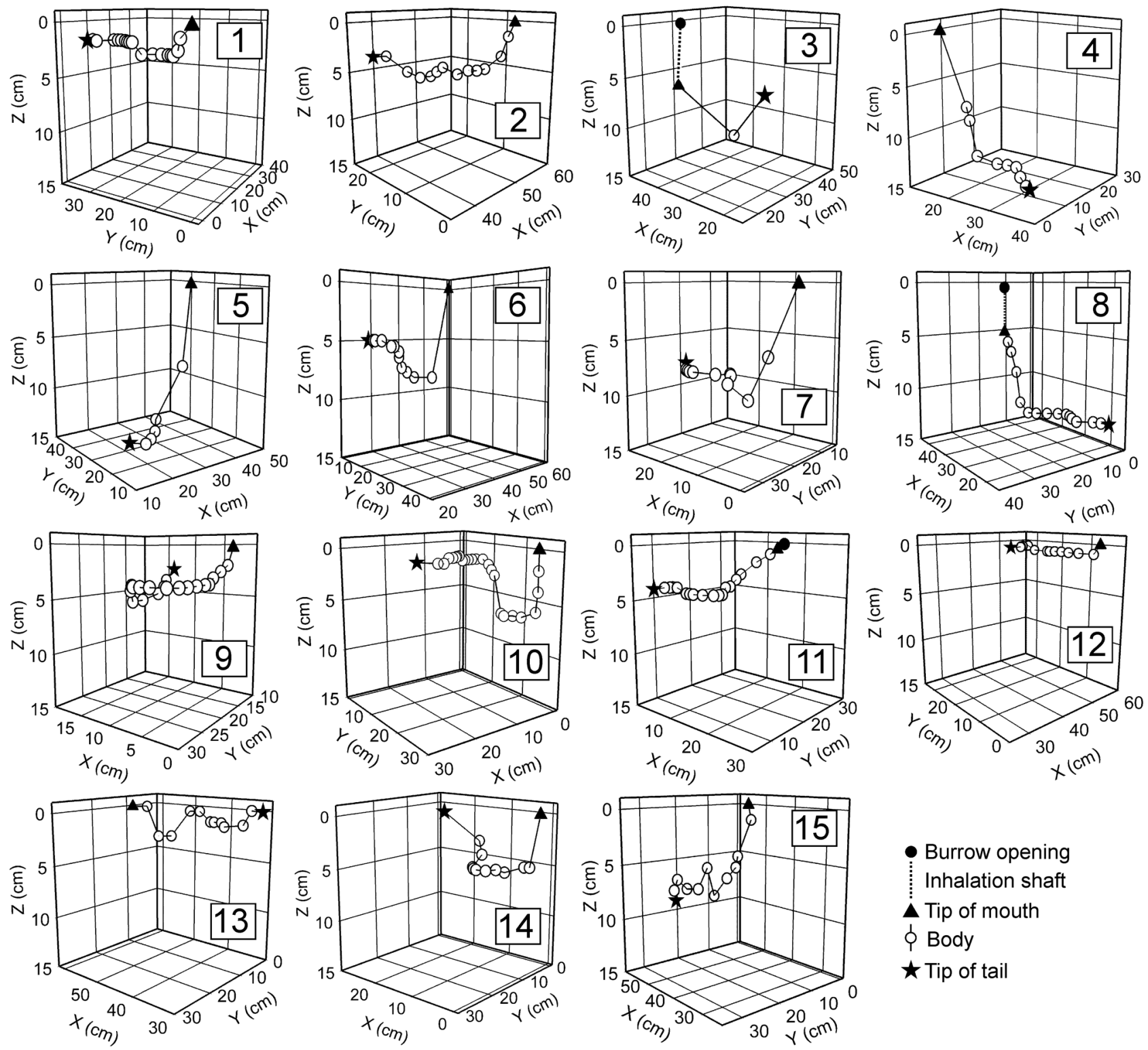

Fig. 1. Anguilla rostrata. Three-dimensional configurations of burrows in mud based on 15 excavation experiments (see Table 1). $\mathrm{X}$ and $\mathrm{Y}$ axes appear in various positions because plots were rotated in 3D space to give the clearest depiction of burrow configuration

Burrow openings were classed as crater, mound, flat, or plug (Fig. 2). Crater openings consisted of a broad depression surrounding the burrow entrance. An eel was observed to form a crater around the burrow opening by sporadic movements of its tail. Craters around burrows which led into the substrate at a low angle $\left(<45^{\circ}\right)$ were often asymmetrical, and were formed by the eel's head pushing sediment on one side. In instances where the eel remained retracted within the burrow for prolonged periods, craters were created when sediment eroded from the edges of the opening and fell into the hole. Mound openings had an elevated ring of sediment around a central hole. Sediment rings observed in the field had a darker colour than that of the adjacent surface, suggesting that the ring was formed from subsurface material. On one occasion in the field, we saw particles being ejected from an opening after the eel rapidly retracted from another opening. Continued deposition of material in this way could lead to mound formation. In flat openings, the burrow entrance was flush with the substrate surface. In plug openings, the opening was entirely filled by the eel, often with only the tip of the eel's head or its lips visible at the 
Flat opening
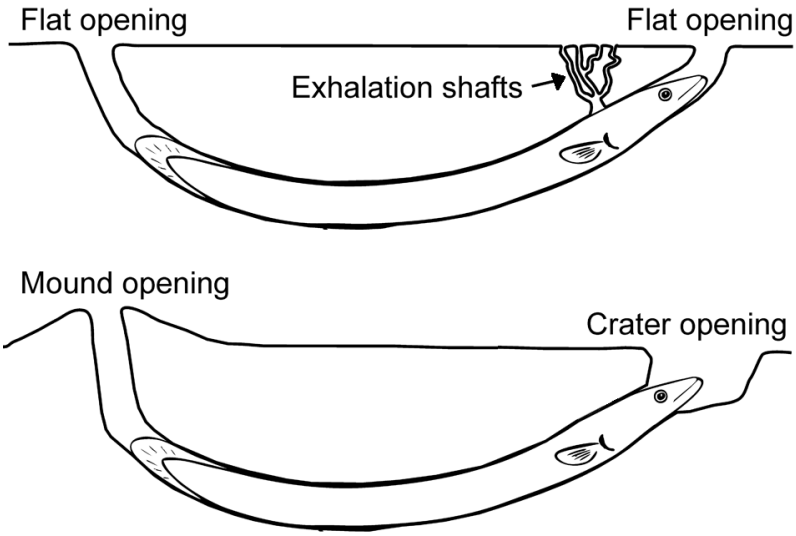

Fig. 2. Anguilla rostrata. Burrows showing flat, mound, and crater openings

substrate surface. Plug openings were surrounded by flat sediment. Of 88 openings of winter burrows, most were crater $(30 / 88,34 \%)$, flat $(32 / 88,36 \%)$, or plug $(22 / 88,25 \%)$ (Table 2$)$. Most $(20 / 32,63 \%)$ openings observed in summer and fall were flat, and none was crater or mound. The maximum number of observed openings per burrow was 4 in the Morell River estuary and 5 in the laboratory.

Wintering burrows located in the Morell River estuary were concentrated in specific areas, in water depths of 1 to $1.5 \mathrm{~m}$. We were unable to find burrows in nearby waters of shallower, similar, or deeper depths. Burrow openings in 9 hole-clusters had a mean diameter of $4.0 \pm 2.6 \mathrm{~cm}$ (range: 1.4 to $10.4, \mathrm{n}=17$; Table 3 ). The mean distance between openings within a cluster was $42.7 \pm 16.5 \mathrm{~cm}$ (range: 17.1 to $73.5, \mathrm{n}=10$ ). Mean $( \pm \mathrm{SD})$ eel lengths in the Morell estuary, visually estimated during nighttime glass-bottom boat surveys, were $52.1 \pm 11.3 \mathrm{~cm}(\mathrm{n}=118)$ (J. Hallett, D. Cairns \& S. Courtenay unpubl.).

\section{Mode of ventilation while in burrows}

Methylene blue dye released just above the mouths of eels buried in mud or pebbles was visibly drawn into the mouth as the animal inhaled. Eels sometimes performed coughing actions for several seconds following initial contact with the dye, which temporarily reversed dye flow. In the pebble substrate, a blue halo formed around the gills about $10 \mathrm{~s}$ after the dye was released (Fig. 3A). After about $3 \mathrm{~min}$, the halo expanded to a maximum radius of approximately 4 to $5 \mathrm{~cm}$ from the gills, after which the halo became increasingly diluted. No visible halo formed around the gills of eels buried in mud. Instead, small exhalation shafts, approximately 1 to $2 \mathrm{~mm}$ in diameter, formed between the gill area and the surface. Blue dye could be seen rising in these shafts and dispersing in the overlying water (Fig. 3B). About $10 \mathrm{~s}$ elapsed between the release of the dye at the eel's mouth and the appearance of dye at the mud surface. Exhalation shafts were observed only during dye experiments, but small plumes of particles rising from the substrate suggested their presence during other lab experiments and in the Morell River estuary. No dye movement along the body was observed in eels buried in either mud or pebbles.

Table 2. Anguilla rostrata. Number of mud burrow openings observed by data source, season, and type

\begin{tabular}{|c|c|c|c|c|c|c|}
\hline \multirow{2}{*}{ Data source } & \multirow{2}{*}{ Season } & \multicolumn{5}{|c|}{ Type } \\
\hline & & Crater & Mound & Flat & Plug & Total \\
\hline Excavation experiments & Fall & 0 & 0 & 5 & 10 & 15 \\
\hline Dye experiments & Late summer & 0 & 0 & 0 & 3 & 3 \\
\hline Substrate experiments & Summer & 0 & 0 & 7 & 7 & 14 \\
\hline Substrate experiments & Winter & 22 & 2 & 28 & 22 & 74 \\
\hline Field observations & Winter ${ }^{a}$ & 8 & 2 & 4 & 0 & 14 \\
\hline Total summer-fall & & 0 & 0 & 12 & 20 & 32 \\
\hline Total winter & & 30 & 4 & 32 & 22 & 88 \\
\hline Grand total & & 30 & 4 & 44 & 42 & 120 \\
\hline
\end{tabular}

Table 3. Anguilla rostrata. Characteristics of burrows in the Morell River estuary, Prince Edward Island, in May and December 2009. Openings are noted by A, B, and C. - not applicable

\begin{tabular}{|c|c|c|c|c|c|c|c|}
\hline \multirow[t]{2}{*}{ Burrow } & \multirow{2}{*}{$\begin{array}{c}\text { Date } \\
\text { (d mo yr) }\end{array}$} & \multicolumn{3}{|c|}{ Opening diameter $(\mathrm{cm})$} & \multicolumn{3}{|c|}{ Distance between openings $(\mathrm{cm})$} \\
\hline & & A & B & $\mathrm{C}$ & $\mathrm{A}-\mathrm{B}$ & $\mathrm{A}-\mathrm{C}$ & $\mathrm{B}-\mathrm{C}$ \\
\hline 1 & 6 May 09 & 4.7 & 2.5 & 5.7 & 33.5 & 53.3 & 34.6 \\
\hline 2 & 6 May 09 & 2.5 & 2.2 & - & 31.2 & - & - \\
\hline 3 & 6 May 09 & 10.4 & 6.5 & - & 73.5 & - & - \\
\hline 4 & 6 May 09 & 1.6 & 2.5 & - & 17.1 & - & - \\
\hline 5 & 6 May 09 & 8.9 & 5.9 & - & 36.2 & - & - \\
\hline 6 & 6 May 09 & 4.1 & - & - & 59.6 & - & - \\
\hline 7 & 9 Dec 09 & 1.4 & 2.5 & - & 36.5 & - & - \\
\hline 8 & 9 Dec 09 & 3.3 & - & - & - & - & - \\
\hline 9 & 9 Dec 09 & 2.1 & 1.7 & - & 51.7 & - & - \\
\hline \multicolumn{4}{|c|}{ Mean, all openings and distances } & 4.0 & & & 42.7 \\
\hline \multicolumn{4}{|c|}{ SD, all openings and distances } & 2.6 & & & 16.5 \\
\hline
\end{tabular}




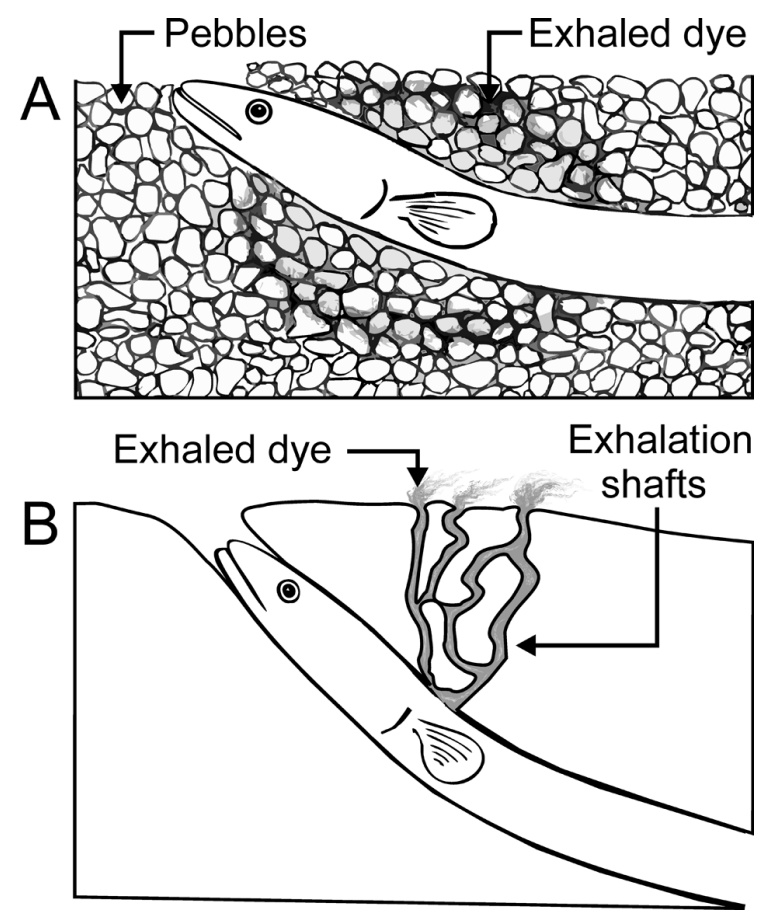

Fig. 3. Anguilla rostrata. (A) Dye forming a halo around the gills of an eel in pebble substrate $10 \mathrm{~s}$ after dye release at the mouth. (B) Dye leaving the network of exhalation shafts in a mud burrow 5 to $10 \mathrm{~s}$ after dye release at the mouth

\section{DISCUSSION}

\section{Burrowing behaviour}

American eels readily burrow into mud, sand, and fine gravel, and also occupy interstitial spaces in cobble substrates. In common with many other burrowing fishes, anguillid eels possess an elongated body and short fins, which facilitate burrowing (Mehta et al. 2010). These features are paralleled in terrestrial fossorial vertebrates, which typically have long bodies and reduced or absent limbs (Gans 1975). Most burrowing fish enter the substrate head-first, including the American sand lance Ammodytes americanus (DeKay 1842) (Meyer et al. 1979), the snake blenny Lumpenus lampretaeformis (Walbaum 1792) (Atkinson et al. 1987), and the Japanese hagfish Eptatretus burgeri (Girard 1855) (Fernholm 1974). Garden eels (Heterocongrinae) burrow tail-first (De Schepper et al. 2007a), whereas the Indian snake eel Pisodonophis boro (Hamilton 1822) is capable of burrowing both head-first and tail-first (De Schepper et al. 2007b). The present study has shown that American eels are head-first burrowers, but after a burrow is constructed, the animal can readily move through it in either a head-first or tail-first direction.
Anguillid eel burrowing behaviour begins as early as the glass eel stage, which is the first stage to contact bottom substrates (Dou \& Tsukamoto 2003). Schafer (1972) reported that yellow European eels Anguilla anguilla (Linnaeus 1758) make burrows by swimming rapidly through open water and then ramming their heads into the substrate, while continuing body and tail undulations. No instances were observed in the present study of eels using swimming momentum to aid in initial penetration of the substrate, even when they were housed in a $200 \mathrm{~cm}$ long tank, which would have facilitated a rapid swimming approach to the substrate. Instead, burrowing into mud, sand, and gravel typically began from a resting position on the substrate surface. When presented with cobble, eels merely passed through interstitial spaces without displacing substrate material. Similarly, Lecomte-Finiger \& Prodon (1979) found that European eel elver substrate penetration behaviour depended on particle size. Elvers could easily enter the interstitial spaces of substrates with a particle size $>2 \mathrm{~mm}$, but required active burrowing to enter substrates with a particle size $<2 \mathrm{~mm}$.

Gillis (1998) described anguillid eel locomotion in water and on land surfaces. Eels advance through water by tail movements, while on land they use sinusoidal undulations of the entire body. Configurations of burrowed eels reported in the present study give clues to the locomotory mode in a third medium, that of mud. Eels in mud burrows were typically curved throughout their bodies, but unlike eels moving on land and water, curves were highly irregular. Animals burrowing through mud commonly use a 'dual-anchor' system, in which the animal alternates between anchoring with the posterior region while forcing the head forward, and anchoring with the head while drawing up the posterior region (Dorgan et al. 2006). Anguillid eels moving on land use surface irregularities as sites of resistance for thrust production; but friction with these sites often fails, causing a slowing of speed (Gillis 1998). In contrast, friction with a 3dimensional mud medium is likely to be higher, allowing the eel to generate thrust in a variety of body positions. The variability of subterranean postures found in American eels contrasts with the regular body undulations that the Indian snake eel uses to advance through both sand and water (Herrel et al. 2011).

\section{Burrow morphology}

Mud burrows mapped in excavation experiments shared several characteristics. The head was usually 
closer to the surface than the rest of the body, and eels had some degree of body curvature. According to Atkinson \& Taylor (1991), fish burrows can be classed as either horizontal or vertical. The burrows observed in the present study qualify as horizontal burrows, but in 3 of 15 cases, the shallow depth of aquarium mud may have constrained burrow depth. Horizontal burrows were also reported for the Japanese eel (Aoyama et al. 2005). Although reversal of eel orientation within burrows was recorded in the lab and in the field, no enlarged interior chambers were found during burrow excavations. Since the walls of a mud burrow are not rigid, it is possible for an eel to reverse its orientation without creating a permanent chamber. Orientation reversals may have been the cause of the large diameter of Japanese eel burrows reported by Aoyama et al. (2005). Orientation reversals have also been recorded in other burrowing fish, e.g. the Japanese hagfish (Fernholm 1974).

Craters and mounds around burrow openings were common in winter, but were not observed in summer and fall. Seasonal differences in the presence of such features may be due to the time required for them to form. Burrow openings were surrounded by flat sediment when first constructed, but over time, eel movements and erosional processes produced craters or mounds around some openings. Winter burrows in the lab were typically occupied for weeks or months, giving craters and mounds time to form, but occupancy of summer and fall burrows was constrained by the short duration of experiments (typically $\leq 2 \mathrm{~d}$ ). Crater burrow openings described in the present study represent the characteristic pock marks of winter burrows reported by Smith \& Saunders (1955). Eel burrows were not detected in extensive glass-bottom boat surveys for American eels conducted at night in spring and summer in southern Gulf of St. Lawrence bays, estuaries, and freshwater ponds (J. Hallett, D. Cairns, and S. Courtenay unpubl. data). Mound and crater burrow openings are easily visible and would have been seen from the glass-bottom boat if present. This suggests that eel burrowing does not produce craters and mounds in summer. Flat and plug openings are less conspicuous and could be missed by observers. In particular, plug openings in which only the eel's lips reach the surface are very inconspicuous and are unlikely to be detected except at close range.

Multiple-opening burrows form when an eel enters the substrate at one point, and then creates further openings to allow inhalation. Multiple-opening burrows have been reported for the Japanese eel (Aoyama et al. 2005) and other fishes (e.g. the eel goby Taenioides cirratus [Blyth 1860], Itani \& Uchino 2003).

\section{Ventilation while in burrows}

Dye experiments confirmed branchial respiration in buried eels because the dye, injected at the bottom of the water column, was observed being drawn into the mouth and leaving the gills. In addition, excavation experiments and field observations indicated that eels buried in mud positioned their mouths in a way that gave access to the water column, either directly at the substrate surface, or via a shaft running from the surface to the mouth. Branchial respiration also requires a means to dispel water rejected from the gills; this was accomplished by small exhalation shafts leading to the surface (Schafer 1972, the present study). Buried sand lance (Ammodytes spp.) also breathe branchially, but draw oxygenated water through sand interstices rather than via a tunnel (Behrens et al. 2007). The method of sucking respiratory water through a sediment layer is unlikely to be viable for eels in mud, because the fine spaces between mud particles would prevent adequate quantities of oxygenated water from reaching the buried eel.

Anguillid eels and many other fish are capable of using both cutaneous and branchial respiration, often simultaneously (Berg \& Steen 1965, Feder \& Burggren 1985). During dye experiments, movement of coloured water along the skin was not observed, which suggests that the skin was not actively drawing water from the surface for respiratory purposes. Our experiments do not preclude the possibility of cutaneous gas exchange with interstitial water in mud. However, passive diffusion of oxygenated water into sand substrates is limited to the top few millimetres (Behrens et al. 2007), and interstitial spaces between mud particles are smaller than those of sand. It therefore appears unlikely that cutaneous respiration is a significant oxygen source for eels buried in mud.

\section{Conservation implications of burrowing behaviour}

Concealment in the substrate during day and during winter is a major feature of American eel behaviour. Fish commonly burrow to reduce predation risk (Atkinson \& Taylor 1991). Use of substrate concealment to reduce predation risk may be especially important to anguillid eels, because their burst swimming speed is much lower than that of typical fish of fusiform shape (Wolter \& Arlinghaus 2003). Hence anything that impairs normal substrate occupancy by eels imposes a conservation risk. Because eels in the substrate breathe branchially, sediment anoxia should not impair respiration. However, widespread 
anthropogenic eutrophication is causing increasing anoxia and hypoxia in coastal waters around the world (Diaz \& Rosenberg 2008), and some shallow bays and estuaries of the southern Gulf of St. Lawrence commonly develop anoxic zones in summer and early fall (Schein et al. 2011). Because eels in burrows respire water from the water column, they cannot use substrate habitat in anoxic zones. The invasive swim bladder parasite Anguillicola crassus is considered a major threat to American eel conservation (Aieta \& Oliveira 2009, COSEWIC 2012). This parasite makes eels more susceptible to low oxygen conditions (Gollock et al. 2005, Lefebvre et al. 2007), which may exacerbate impacts of anthropogenically induced anoxia/hypoxia on yellow eels.

Acknowledgements. We thank L. Anderson, M. Boudreau, C. Desjardins, T. Goff, J. Jenkins, D. MacDonald, J. Mallory, B. Murray, E. O'Brien, S. Ratelle, M.-H. Thériault, and the staff of the Mactaquac Biodiversity Facility for their valued assistance.

\section{LITERATURE CITED}

Aieta AE, Oliveira K (2009) Distribution, prevalence, and intensity of the swim bladder parasite Anguillicola crassus in New England and eastern Canada. Dis Aquat Org 84:229-235

- Aoyama J, Shinoda A, Sasai S, Miller MJ, Tsukamoto K (2005) First observations of the burrows of Anguilla japonica. J Fish Biol 67:1534-1543

Atkinson RJA, Taylor AC (1991) Burrows and burrowing behaviour of fish. Symp Zool Soc Lond 63:133-155

Atkinson RJA, Pelster B, Bridges CR, Taylor AC, Morris S (1987) Behavioural and physiological adaptations to a burrowing lifestyle in the snake blenny, Lumpenus lampretaeformis, and the red band-fish, Cepola rubescens. J Fish Biol 31:639-659

Behrens JW, Stahl HJ, Steffensen JF, Glud RN (2007) Oxygen dynamics around buried lesser sandeels Ammodytes tobianus (Linnaeus 1785): mode of ventilation and oxygen requirements. J Exp Biol 210:1006-1014

> Benedetti M, Gorbi S, Notti N, Fattorini D and others (2008) An ecotoxicological protocol with European eel, Anguilla anguilla, to assess the quality of marine sediments. Comp Biochem Physiol A 151(Suppl):S25

Berg T, Steen JB (1965) Physiological mechanisms for aerial respiration in the eel. Comp Biochem Physiol 15:469-484

Bozzano A (2003) Vision in the rufus snake eel, Ophichthus rufus: adaptive mechanisms for a burrowing life-style. Mar Biol 143:167-174

Cairns DK, Tremblay V, Caron F, Casselman JM and others (2008) American eel abundance indicators in Canada. Can Data Rep Fish Aquat Sci 1207. Fisheries and Oceans Canada, Ottawa

Casselman JM (2003) Dynamics of resources of the American eel, Anguilla rostrata: declining abundance in the 1990s. In: Aida K, Tsukamoto K, Yamauchi K (eds) Eel biology. Springer, Tokyo, p 255-274

Colodey AG, Wells PG (1992) Effects of pulp and paper mill effluents on estuarine and marine ecosystems in Canada: a review. J Aquat Ecosyst Health 1:201-226

COSEWIC (Committee on the Status of Endangered Wildlife in Canada) (2012) COSEWIC assessment and status report on the American eel (Anguilla rostrata) in Canada. COSEWIC, Ottawa

Cote CL, Gagnaire PA, Bourret V, Verreault G, Castonguay M, Bernatchez L (2013) Population genetics of the American eel (Anguilla rostrata): $\mathrm{F}_{\mathrm{ST}}=0$ and North Atlantic Oscillation effects on demographic fluctuations of a panmictic species. Mol Ecol 22:1763-1776

> Damjanovic I, Byzov AL, Bowmaker JK, Gacic Z and others (2005) Photopic vision in eels: evidences of color discrimination. Ann N Y Acad Sci 1048:69-84

> De Schepper N, De Kegel B, Adriaens D (2007a) Morphological specializations in Heterocongrinae (Anguilliformes: Congridae) related to burrowing and feeding. J Morphol 268:343-356

> De Schepper N, De Kegel B, Adriaens D (2007b) Pisodonophis boro (Ophichthidae: Anguilliformes): specialization for head-first and tail-first burrowing? J Morphol 268:112-126

Dekker W, Casselman J, Cairns DK, Tsukamoto T, Jellyman D, Lickers H (2003) Worldwide decline of eel resources necessitates immediate action: Québec declaration of concern. Fisheries (Bethesda) 28:28-30

> Diaz RJ, Rosenberg R (2008) Spreading dead zones and consequences for marine ecosystems. Science 321:926-929

Dorgan KM, Jumars PA, Johnson BD, Boudreau BP (2006) Macrofaunal burrowing: the medium is the message. Oceanogr Mar Biol Annu Rev 44:85-121

$>$ Dou SZ, Tsukamoto K (2003) Observations on the nocturnal activity and feeding behavior of Anguilla japonica glass eels under laboratory conditions. Environ Biol Fish 67: 389-395

- Feder ME, Burggren WW (1985) Cutaneous gas exchange in vertebrates: design, patterns, control, and implications. Biol Rev Camb Philos Soc 60:1-45

Fernholm B (1974) Diurnal variations in the behaviour of the hagfish Eptatretus burgeri. Mar Biol 27:351-356

Gans C (1975) Tetrapod limblessness: evolution and functional corollaries. Am Zool 15:455-467

Gillis GB (1998) Environmental effects on undulatory locomotion in the American eel Anguilla rostrata: kinematics in water and on land. J Exp Biol 201:949-961

Glova GJ (2002) Density effects on juvenile short-finned eel (Anguilla australis) cover preferences in replicate channels. N Z J Mar Freshw Res 36:483-490

Gollock MJ, Kennedy CR, Brown AJ (2005) European eels, Anguilla anguilla (L), infected with Anguillicola crassus exhibit a more pronounced stress response to severe hypoxia than uninfected eels. J Fish Dis 28:429-436

> Herrel A, Choi HF, Dumont E, De Schepper N, Vanhooydonck B, Aerts P, Adriaens D (2011) Burrowing and subsurface locomotion in anguilliform fish: behavioral specializations and mechanical constraints. J Exp Biol 214: 1379-1385

Higgins RP, Thiel H (1988) Introduction to the study of meiofauna. Smithsonian Institution Press, Washington, DC

> Itani G, Uchino T (2003) Burrow morphology of the goby Taenioides cirratus. J Mar Biol Assoc UK 83:881-883

Jessop BM, Cairns DK, Thibault I, Tzeng WN (2008) Life history of American eel Anguilla rostrata: new insights from otolith microchemistry. Aquat Biol 1:205-216

Kennish MJ (2002) Environmental threats and environmen- 
tal future of estuaries. Environ Conserv 29:78-107

Lamson HM, Shiao J, Iizuka Y, Tzeng W, Cairns DK (2006) Movement patterns of American eels (Anguilla rostrata) between salt- and freshwater in a coastal watershed, based on otolith microchemistry. Mar Biol 149:1567-1576

Lecomte-Finiger R, Prodon R (1979) Étude expérimentale du comportement fouisseur de la civelle (Anguilla anguilla L): le choix d'un substrat. C R Acad Sci Paris 289:741-743

Lefebvre F, Contournet P, Crivelli AJ (2007) Interaction between the severity of the infection by the nematode Anguillicola crassus and the tolerance to hypoxia in the European eel Anguilla anguilla. Acta Parasitol 52:171-175

Lotze HK, Lenihan HS, Bourque BJ, Bradbury RH and others (2006) Depletion, degradation, and recovery potential of estuaries and coastal seas. Science 312:1806-1809

Marcogliese LA, Casselman JM (2009) Long term trends in size and abundance of juvenile American eels ascending the upper St Lawrence River. Am Fish Soc Symp 58: 191-205

Mehta RS, Ward AB, Alfaro ME, Wainwright PC (2010) Elongation of the body in eels. Integr Comp Biol 50: 1091-1105

Ménard A, Turgeon K, Kramer DL (2008) Selection of diurnal refuges by the nocturnal squirrelfish, Holocentrus rufus. Environ Biol Fish 82:59-70

Meyer TL, Cooper RA, Langton RW (1979) Relative abundance, behavior, and food habits of the American sand lance, Ammodytes americanus, from the Gulf of Maine. Fish Bull 77:243-253

Santiago R, Pelletier J (2001) Contaminated sediment management: the Canadian experience. Water Qual Res J Can 36:395-411

Editorial responsibility: Victor Meyer-Rochow, Bremen, Germany
Schafer W (1972) Ecology and palaeoecology of marine environments. Oliver Boyd, Edinburgh

Schein A, Courtenay SC, Crane CS, Teather KL, van den Heuvel MR (2011) The role of submerged aquatic vegetation in structuring the nearshore fish community within an estuary of the southern Gulf of St Lawrence. Estuaries Coasts 35:799-810

Smith MW, Saunders JW (1955) The American eel in certain fresh waters of the maritime provinces of Canada. J Fish Res Board Can 12:238-269

Tesch FW (2003) The eel, 3rd edn. Blackwell Science, Oxford

> Thomas MLH (1968) Overwintering of American lobsters, Homarus americanus, in burrows in Bideford River, Prince Edward Island. J Fish Res Board Can 25:2725-2727

Tomie JPN (2011) The ecology and behaviour of substrate occupancy by the American eel. MSc thesis, University of New Brunswick, Fredericton

US Department of the Interior (2007) 12 month finding on a petition to list the American eel as Threatened or Endangered. Fed Regist 72:4967-4997

Vladykov VD (1955) Eel, fishes of Quebec. Album 6. Department of Fisheries, Quebec, p 1-12

Weissberger EJ, Coiro LL, Davey EW (2009) Effects of hypoxia on animal burrow construction and consequent effects on sediment redox profiles. J Exp Mar Biol Ecol 371:60-67

> Wentworth CK (1922) A scale of grade and class terms for clastic sediments. J Geol 30:377-392

> Wolter C, Arlinghaus R (2003) Navigation impacts on freshwater fish assemblages: the ecological relevance of swimming performance. Rev Fish Biol Fish 13:63-89

Submitted: April 12, 2013; Accepted: September 6, 2013 Proofs received from author(s): November 2, 2013 